\title{
Entering into a community-university collaboration: Reflections from Blue Mountain Associates
}

\section{FoodDignity}

\author{
Virginia J. Sutter* \\ Blue Mountain Associates, Inc.
}

Submitted April 11, 2018 / Published online July 18, 2018

Citation: Sutter, V. J. (2018). Entering into a community-university collaboration: Reflections from Blue Mountain Associates. Journal of A griculture, F ood Systems, and C ommunity D evelopment, 8(Suppl. 1), 13-15.

https:/ / doi.org/ 10.5304/ jafscd.2018.08A.012

Copyright @ 2018 by the Author. Published by the Lyson Center for Civic Agriculture and Food Systems. Open access under CC BY license.

$\mathrm{I}_{\mathrm{f}}$ f I can do something to help my people, and to help other people understand Indian people better and to appreciate our culture, then I have done what my father asked me to do in 1969 when he asked me to come home to the reservation and help my people in whatever way I could. In the last 50 or 60 years of my life, with the assistance of other people, I have been able to make some changes.

When my son, Jim Sutter, and I came back home to Wind River Indian Reservation, we knew our people needed health and human services, not just more clinical services. We thought we especially needed to help people with food and nutrition. More generally, I thought that other peopleresearchers, academics, historians - need a better picture of what we Indians are all about in ways that neither glorify us nor demean us. Too often we are portrayed only on one side or the other.

So, when D r. Christine Porter called me in

* Dr. Virginia J. Sutter, Founding Executive D irector, Blue Mountain Associates, Inc. (http:/ / bluemountainassociates.

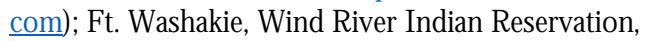
Wyoming, USA; drvsutter@wyoming.com
2010 to ask if Blue Mountain Associates (BMA) would like to collaborate with the University of Wyoming regarding a grant called Food Dignity, it seemed to fit exactly what we were looking for. We thought we should collaborate with Christine because she has the academic background, while we know the people. We know their abilities. We know their culture and history. Between the two organizations, we could correct a lot of the wrongs done to this reservation.

However, Jim and I needed to think about what would be the best way to do that. We were concerned that we had only worked with Indian programs, and this would be our first experience working with a university that was not an Indian group. Over the years, so many researchers have come from the outside to study Indian people, and we have had to overcome a lot of inadequate and inaccurate studies about our people. We don't forget those things, just like we don't forget genocide attempts against our people. It's not written, but it comes down through our history. We have storytellers and historians who keep accurate records of what happens in our tribe. 
With the knowledge we had of this, we knew it was going to take a very special program to reach our people and have them to trust us to do it the Indian way while still satisfying our funders. Many academic people are kind of pushy, and that was a hurdle that we thought we would have to get over. A lot of people had tried and given up. A lot of people in Indian country had gotten discouraged and just didn't feel like they were getting to have any say in partnerships like this. It often turned into a bunch of white people bossing them around, when what we wanted was to be included in the planning and to be in charge of implementation, to become the ones actually doing the program.

I remember how uneasy I was when I brought Christine to present the Food Dignity program to the Joint Council of the Eastern Shoshone and Northern Arapaho tribes. I thought there was a chance they would throw us out, but they were very polite. Christine made her presentation in a respectful and dignified way, with no "you have to" or "you need to," and it turned out they were our best allies. Christine was the kind of person that blended in well with the Indian culture. She didn't push and yell, but instead was soft-spoken and asked us how we would like to do things.

That really impressed me when we started with Food Dignity. There was no rush, no pushing or shoving. It was more like joining hands with all the Food D ignity partners and saying "let's do this together," with the University of Wyoming, Cornell University, and four other community partnersWhole Community Project, East New York Farms!, Feeding Laramie Valley, and Dig D eep Farms. The project respected that each community would have its own culture, environment, growing season, and community input. Y et we all had to address the same problem of trying to ensure everyone has access to abundant and nourishing food, both now and in future generations. We said: you show us what works for you and we'll show you what works for us, and then we'll work together to blend those in a way so that the people giving us the grant will be satisfied, and on the reservation we'll find some information about what really works best for our health.

We needed that information from the community. The best thing we could do was gather the leaders and talk to them directly. So when we got the community group together, we chose leaders from each tribe. We invited people who were well thought of, people who had been leaders all their lives, to whom other people listen, whose relatives in the tribe had respect. They were very willing to work with us. O ne of our best collaborators was a close relative of Chief Washakie among the Shoshones. We also had my ties to the Northern Arapaho Chief Sharpnose, who was my greatgrandfather.

Each day BMA became closer to the community, and the university became more comfortable working with BMA in learning about Indian culture. And what impressed me the most in the first year was that both tribes sat down together and worked together in a program with no dissention. Historically those two groups did not get along together, and then to work with white people, too, involved three cultures. It was a real hurdle to get those three cultures on the same page. And in the very first year of Food D ignity, we were able to do this.

And then we invested in the community directly. Many people had never had enough money to buy seeds and other supplies they needed to grow food commercially. With support from BMA, in the Food Dignity program, with the money people could buy and plant seeds. For example, one family started with just US\$2,000 to help them get started with raising chickens to share and to sell eggs in our community. They grew that into a chicken business and then started two more businesses. A member of their family has published a book for children with stories from our culture. Another community member used to have just two horses on her land. Now she has developed a big garden, is a growing lot of potatoes, and has shown our community how to build a root cellar like our ancestors did. She keeps her potatoes, her cabbages, and her canned fruits there. Her brother cut the wood for the cellar from the mountain, and with all the food she was growing for her family and selling at the farmers market, she was able to help buy her brother some breeding horses. Consider these little bits of money and look what they did with it. With little starts like that people can go out and do a lot of things. 
When we look back, we are really proud that people accepted the money not as a token gift, but as an investment in their lives to be something, to do something. They didn't think it was welfare, and they made good use of it. They showed us what they had done with their money to the dime. A lot of people in a situation like that would take the money and forget about it, but every one of the people we worked with was part of the community, and our community leaders were behind them and were watching them. I think that is why we had such good luck. Together we made a world of difference in the approach to promote better health and food sustainability among our tribal people on the Wind River Reservation. 